\title{
The Ideology of Objectivity: Constructs of Language in the Popular Press of Early Twentieth-Century Britain
}

\author{
CLAUDIA HESKE, University of Pittsburgh
}

\begin{abstract}
Relying on archival research, particular events occurring during the First World War will be singled out that generated articles in the popular press, and acts of close reading will be performed to see which journalistic styles and techniques are being used to relate the details of wartime events. I will also explore how imperialism is featured, either as an implicit or an explicit construct, when journalists write articles concerning global affairs. This focus on the thematic representation of war and the epistemological supposition of an imperialist order in newspapers will show the ways in which a nationalist discourse is configured. Newspaper reports are ideally thought of as a transparent and impartial medium. However, in studying the links between the mass production and circulation of popular newspapers, the dramatic increase of a literate public, and the state of the British imperialist project in the early twentieth century, journalism's so-called transparent discourse can be fundamentally questioned.
\end{abstract}

\section{KEYWORDS}

imperialism, journalism, discourse, objective, mode of production.

\section{Introduction}

By the start of the Great War in August 1914, the newspaper industry in Great Britain was just beginning to standardise a new set of practices. We usually call this modernized formation of the mainstream national press the 'New Journalism'. The 'New Journalism' conceived of itself as 'the champion of the people' (Hampton, 2004, p. 76) holding itself at a distance from political parties and their self-interested agendas. This disinterested press claimed the responsibility to inform and educate the mass public on political and cultural issues and world events. At this time, the industry became particularly powerful because it worked to organize the general public's language about the world around it. How is the world articulated when there is a time of severe crisis, such as war? Is the vision of the world that is presented to the public an evident one? What impact does a publicly circulated discourse about the world have on the social and political practices in the world? The primary task in my larger project, of which this is a part, is to assess what gets constituted in the representational discourses that get circulated in a national newspaper, such as the London Times. Ultimately, examining the politics and formal strategies of journalistic 
practices in turn-of-the-century Britain may raise questions for us about the discursive construction of war in our own time with the availability of new media technologies.

At the end of the nineteenth century, Britain is marked by the paradoxes of a developing democratic nation: electoral democracy gains popularity at the height of imperial colonialism, which is maintained by autocratic rule, the working classes massively begin to organize 'at a time when probably capitalism offered them slightly less miserable conditions than before' (Hobsbawm, 1989, p. 10) and, 'an industrial proletariat and a new bourgeoisie or middle class emerged as self-conscious groups at about the same time' (Hobsbawm, 1989, p. 183) making it difficult for social classes to distinguish themselves from one another by consumer choices or cultural tastes. Paradoxes like these that arise within the transformative period before the First World War in Britain have their roots in a laissez-faire society, a society that has allowed a self-correcting free market to 'resolve' the inevitable conflicts while touting liberaldemocratic values. This era of British imperialist expansion came on the scene and complicated the seemingly straight-forward, nation-centered social order: the anonymous unidirectional function of capitalism suddenly must be accountable to and work in the interest of multiple and diverse groups of people in an international arena. The new modus operandi of capitalism at this time required the transformation of cultural phenomena, as it did political and economical structures.

The extreme conditions of the imperial era inadvertently resulted in the democratization of the society-as evidenced by the multiple reformist acts of the 1860 s and the 1880s, especially the campaigns for literacy. These efforts lent new visibility to a neglected and exploited segment of the population: the poor and the working classes. However, these processes of democratization also gave the ruling classes an opportunity to manipulate the appearance of the social system, which came to embrace the centrality of voting rights but cared little for economic rights. In other words, the naked economic determinants of capitalism became concealed behind the curtain of universal suffrage, which appeared to be then, as it does now, the social equalizer of the new century. Numerous debates surrounded the 'New Journalism' of the Edwardian era. It became politically and socially important to answer the question, did popular newspapers contribute to the growing empowerment of the disenfranchised, or did they help to contain the evolution of radical politics?

Of the various contesting voices weighing in on the press, one becomes predominant, proclaiming that it will reason from 'the point of view of the universe'. (Collini, 1991, p. 57) This voice was a liberal-progressive one, echoing a new social reality ushered in by the contradictory relationship of imperialism and electoral democracy. It spoke of a civilized society weighed down by a white man's burden, guided by logic, rule of law, and the belief in the progressive promise of liberal institutions. This was the voice of the era of imperialism which was, to quote Eric Hobsbawm, (1989, p. 73) 'the child of an era of competition between rival industrial-capitalist national economies'.

At this point in the history I am discussing, Britain was in a process of 'turning away from a capitalism of the private and public policies of laissez-faire' and moving toward 'the rise of large corporations and oligopolies as well as the increased intervention of the state in economic affairs' (Hobsbawm, 1989, p. 73). This historical-materialist view of the period has a paradoxical relationship with the liberal 
ethos used to justify it: the growing convergence between economics and politics made the 'free-exchange' ideal of laissez-faire less free and more contingent upon strict management of business and public policy. This paradox is not only apparent today, but it was also conveyed in material ways by the cultural media of the time. The above gloss of a moment in imperial history, as the Empire grappled with the paradoxes of nineteenth-century liberal bourgeois society, indicates the possibilities and the limitations of media-produced discourse. In what follows, the essay will explore the connections between the form, content, and production of a national media in order to discover how discourse is ideologically constructed. It is clear to me that the ideological impact of discourse during wartime is more than a matter of semantics: it is a matter of grave importance to national politics. By treating the study of discourse as a process of mapping, I will be able to intimately relate the inner workings of a news office, its cultural product (e.g., the newspaper), and the social conditions in which they are fostered.

It is my tentative view that national identities are shaped in part by the publication practices of periodicals. Nationalism becomes especially crucial for the Empire and its subjects during this period. Eric Hobsbawm's and Benedict Anderson's work shows that nationalism takes on various defining characteristics at the end of the nineteenth century that had not previously been present. One of these characteristics is the element of language as a cohering structure for a nationalist identity. The language amongst the population of a community (a community could be defined as united by one or more things like geographical location, ethnicity, or traditions) becomes a key factor in the new conceptualization of nationalism and is a key component for one theory that argues that nation-states should be understood as 'imagined communities'. In Hobsbawm (1990, p. 12) views 'national consciousness' as developing 'unevenly among the social groupings and regions of a country'. The indeterminable dimension of uneven development makes it difficult to ascertain what the general public's sense of its nation is. To a large extent, the impressionistic findings of social and cultural patterns rely on understanding class or communal bonds, but not necessarily through determined lineage or economic exchange. The process of mapping draws out significant ideas of a community or a class and helps us to conceptualize sets of otherwise ambiguous relations. Benedict Anderson theorizes the relationship of the emergent bourgeoisie of the nineteenth century in the context of a common readership based on print-capitalism this way:

Factory-owner in Lille was connected to factory-owner in Lyon only by reverberation. They had no necessary reason to know of one another's existence; they did not typically marry each other's daughters or inherit each other's property. But they did come to visualize in a general way the existence of thousands and thousands like themselves through print-language.

(Anderson, 1983, p. 77)

Mapping social relations by way of imagining how people bonded through printed material explains how each general class category in early twentieth-century Britain develops its own sense of identity and by which discursive means.

Without delving too deeply into those theories about how political and cultural feelings make a contiguous idea of a nation exist, I do want to take advantage of the analyses of linguistic nationalism brought forward by scholars such as Hobsbawm 
and Anderson in order to further investigate the material ways in which a newspaper can, and did, aid in welding the British nation-state's interests to a nationalist identity. After all, as Hobsbawm (1989, p. 147) has pointed out, 'linguistic nationalism was the creation of people who wrote and read, not of people who spoke'. As a mode of public written communication in a historically unprecedented era of literacy, the newspaper is a product of one of the most revolutionizing industries of the modern era.

A sense of nationalism was centrally important within the newspaper industry itself and widely affected the establishment of the 'New Journalism' model. In a move to have journalists constitute an 'occupational' class, where each member could subsist financially by writing for a newspaper or periodical alone, its practitioners organised themselves. This occurred at two notable historical junctures. The first effort to organize journalists as a group of professionals came in the 1880s with the formation of the Association of Journalists (later to be renamed the Institute of Journalists). The Institute gave little, however, in the way of getting political or economic practices standardised across the whole field of journalism. Rather, it seemed to encourage competition between journalists where each individual worked to please a personal or corporate interest. Membership to the Institute was granted to those who met qualifications outlined by the Institute. As a result, professionalisation meant extending processes of social stratification by economically rewarding those individuals whose work served the immediate interests of the Institute.

By 1906, working journalists, particularly those in the provinces-the lowerpaid sector of the occupation-were never very satisfied with an organisation that took little interest in their material well-being.

(Elliott, 1978, p. 176)

In the ongoing struggles for individual newspaper writers to secure their status and financial stability, a national consciousness surfacing in the general population brought to light possibilities for larger organised efforts to take shape. A national consciousness operated on a scale far surpassing the exigencies of the Institute of Journalists. Finally, after 1906, the NUJ (National Union of Journalists) emerged. In a period of rapid expansion and advanced technologies, the national level of journalism was also becoming associated with its professional status, which was becoming recognized for its highly specialised functions. This professionalisation of the field of journalism is a fundamental feature of its national character because, in the words of James D. Startt, (1988, p. 294) 'as a vehicle of political communication, it was a more comprehensive public institution than its Victorian predecessor'.

A particular aspect of the 'New Journalism' in early twentieth-century Britain is that it evolves along the lines of liberal humanism and capitalist forms of commercialism. It takes shape in an analogous way to the phase of social development that is described above. The media scholar Mark Hampton offers an account of the liberalhumanist strain of the press during this era. He argues that the 'New Journalism' undergoes a shift from an educational to a representative role and that this Fourth Estate model was the best suited for a period of mass democratization movements. He says that the representative idiom largely stems from an 'image of the press as representing 'the people' either more directly or more completely than did Parliament itself' (Hampton, 2001, p. 224). Although Hampton relies heavily on a transitional 
shift from educational to representational modes of journalism, he does not completely evacuate the constitutive educational quality from the popular press of this new period. One might say of Hampton's argument what Stuart Hall said of Gramsci's discussion of the function of the press:

Gramsci means (...) that the press always has this active educative role in relation to the classes and class fractions it 'represents'. He means that the representational role is never a passive, reflexive one.

(Hall, 1978, p. 32-3)

This dialectical character of representation is especially theoretically important when thinking about the dynamic processes of mediation that occur within practices of reading and writing.

Hampton argues that the press became an advocate for growing trends in public life, a showcase for the people's free ideas, praise, or dissent from their government. This press was committed to cultivating a well-informed public, which implied a deep trust in its own authority and ability to select what information best suited the needs of the public. This attribution of authority made the public service role of the press a wellaccepted one. It also brought up a crucial question: How will the popular press maintain this prestige and position of power granted it by the public? The media industry promoted editorial integrity and representational accuracy by professionalizing and commercializing its operations. It did so to such a competent degree that, in fact, many of the industry standards instituted during this period are still upheld today; for instance, the division of labour between owning, editing, leader writing, managing, and reporting; the centralisation of production and control; the concentration of ownership and the dependence on advertising revenue have all become standard if not sought after practices.

At the same time that the market was becoming more homogenized with the increasing concentration of ownership, there was a positive counterweight: even though the industrialisation of the press tended to yield to the pressures of the private sector and the commercial market, these developments led to an expansion of the industry so that not only would political and cultural reading material reach a larger mass of people, newspapers were compelled to appeal to less specific audiences. This is another way of saying that a liberal-bourgeois discourse needed to capture the imagination of the working classes to stay in business. For the first time, the newspaper industry had an opportunity to widely effect social and political change across class lines.

The irony is that in order to succeed in the capitalist marketplace, large industrial complexes necessarily made compromises that had the potential to undermine their very systems of operation. To successfully inform or educate their diverse public, the newspapers had to wager their own business interests against cultural interests of the newly literate but increasingly agitated working classes. Liberal or conservative papers similarly generated a standardised language in order to reach the largest readership possible and to give the impression of a uniform readership. It turns out that this strategy worked in their favour; it created a perception that, perhaps, class stratification did not exist and that free market competition was promoting healthy popular debate. This point of view is convincing only if we believe that true 
democracy can exist at a level of discourse while the real conditions of social and economic inequality remain intact. It would be more apt to understand the adoption of a standardised language as, in Frederic Jameson's (1989, p. 19) phrase, a 'strategy of containment'.

By taking advantage of technologies such as the telegraph, shorthand, the railroad, and advanced printing press machinery (such as steam-powered and rotary presses), reporters were able to claim a greater degree of accuracy in recording information, transmitting it to the home office, committing information to newsprint, and distributing newspapers to a readership. Statistics support the argument that these new modes of production changed the nature of news reporting: for instance, the rise in dailies during the period of implementation of all these technologies shows that a new mode of journalistic production required a new market and, consequentially, it socialised a new reader with new interests. Anthony Smith has associated the technological advances with cognitive changes in a reader's understanding of how society is organised:

The specialism of the journalist, and especially of the editor, lay in knowing what the market required. Reality was categorised into pages-home, overseas, political, women's interest, sport, the City and so on. Special new kinds of events were developed which had not previously existed in human cognition, such as, for example, the 'crisis,' the 'horror,' or the 'human story'. Events acquired 'angles', or rather, special elements which made them more easily communicable within certain sectors of the market.

(Smith, 1978, p. 168)

Smith concludes that, in fact, the journalist has come to "supply the needs of a large social machinery which defines the interim phases of reality' (1978, p. 168). This argument explains the potential of the press to shape its audience's perception and understanding of reality.

It turns out that the journalist was not only developing new interests for a readership, but the journalist was also presenting any new content in a categorical fashion. Events became accessible to a reader by the formal organisation of the information. The question then becomes, does selection and presentation of information in a newspaper derive from a journalist's political orientation? It could be argued that the construction of discourse happens largely at the point of production. Under capitalism, the creative element of writing is value-based, therefore considered to be an output of productive labour. In a capitalist press, then, radical politics could be curtailed by the divisions of labor imposed on workers in that industry, and any communication that is processed commercially could be considered automatically to be corrupt.

The specialisation of the journalist is mobilized by a 'socio-technical division of labour' derived from a:

radical transformation of the literary mode of production, the historical appearance of a new kind of structure suited to, demanded, and provided by the larger structures of emergent monopoly capitalism.

(Feltes, 1986, p. 78-9) 
John Tagg argues that this division of labour:

has produced a multiform ensemble of experts and technicians (...) who have direct and localized relations with particular domains of knowledge and particular institutions, who have an intimate familiarity with the specific constraints which hold there, and who are therefore capable of locating and marking the weak points, the openings, the lines of force.

(Tagg, 1988, p. 93)

It can be argued that this division of labour and increased level of specialisation has the newsman address his subject-matter from a position of alienation. This makes it difficult, if not impossible, for a journalist to express a totalized view of a society; a view that is not compartmentalized like the sections and categories of a 'New Journalism' newspaper. However, this division of labour also makes it possible for someone like a writer or reporter to more immediately intervene in the production of meaning. This is perhaps why new forms of media often offer the promise of prompting social change.

The formal conventions used by the print media at this time, such as the use of headlines or categorisation of stories, are partially responsible for ordering the truth'-for putting loose information into a framework about the world. However, the formal innovations undertaken by the specialised staff of the media industry could not simply reorganise information in whatever fashion it chooses. This was proven when the Times, before 1908, used an old journalistic format in its pages-non-episodic; lengthy columns instead of condensed blocks; advertisements on the first page instead of world or local news, no masthead, and a tone of formal anonymity. That is, it did not grab search outside its traditional readership: it made no effort to appeal to the reader of the new democratic state, who was no longer only the elite and educated man of the Victorian period. Hampton points out that the 'mid-Victorian idealized newspaper reader (...) had masculine, European, and middle-class attributes'. (Hampton, 2004, p. 12) The process of colonisation happening outside the boundaries of the British Isles and the massive organizational working-class movements forming inside the nation in late Victorian times complicated this ideal.

The format of the newspaper needed to be an inclusive one, considering the expanse of the public sphere a national newspaper was reaching. The Times paper's sales increased significantly after 1908 when Alfred Harmsworth, Lord Northcliffe, took over and implemented the changes. Much has been made about Northcliffe's effectiveness at modernizing his newspapers. James Startt (1988, p. 279) points out that 'Northcliffe in matters of attitude was, in fact, the embodiment of middle-class respectability (...) demand[ing] it be a paragon of accuracy in news reporting'. The successful Daily Mail, commonly called the 'Soldier's Paper', was also run by Northcliffe and is a notable forerunner in those innovative, creative techniques and style that reflected middle-class sensibilities. So, in this respect, the design and layout of a newspaper has much to do with its popularity. However, since a newspaper such as the Times appealed to a socially variegated readership, it is possible that the newspaper conveyed other interests than those of the middle classes. Perhaps a reporter could work in the interest of a more radical public. 
Do the structures of language of the new media impede the ability of a journalist to express his own politics? In Late Capitalism, Ernest Mandel forwards this proposition:

the more higher education becomes a qualification for specific labour processes, the more intellectual labour becomes proletarianized, in other words transformed into a commodity.

(Mandel, 1978, p. 260)

If this is the case, does the socio-technical labour process of the newspaper reporter potentially make him a proletarian actor? I would argue that the newspaper reporter's tasks are distinct from the printer's duties (manual labour) or the editor's duties (intellectual labour). All newspapers are certainly not interchangeable and, for that matter, neither are individual reporters whose work makes up the unique characteristics of a newspaper's level of engagement with society. This is why style and expressions from individual journalists are often read as autonomous articulations of a privileged and educated thinker or writer.

The particular stylistic choices of journalists indeed raise questions (then and now) about the potential for an individual to affect structural systems. Nevertheless, the 'independent' and sometimes even oppositional character of intellectual labour often becomes subordinate to the logic of capital as intellectual labour cannot escape structural determinants and works within its framework. Consequentially, a nuanced account of social material that a journalist may intend to produce is often lost when expressed through a monolithic industrialised institution such as the Times. Furthermore, specialisation and the division of labour create hierarchies for private profit; they don't encourage the socialisation of production, which as Mike Wayne (2003, p. 15) reminds us, 'provides the objective possibility and moral necessity to transcend the hierarchical and profit-driven structure of capitalist production'.

Newspaper reporters are firmly middle class 'knowledge workers' because they elaborate and disseminate ideas rather than just use them. However, in contrast to newspaper editors who are also middle class, for instance, journalists' class character is unique in the sense that their location within the social relations of production places them in greater conflict with the forces of production. This can perhaps explain why, in the public's view, journalists are more socially prominent than editors: the cultural worth of the reporter's work comes from his proximity to the social world rather than from his particular work practices within the relations of production. However, this public perception could also account for why individual reporters have only a fleeting influence on the industry they work in. In any case, I think the contestations that occur within the industry can be gleaned from the newspaper articles themselves.

Consider some articles on a page that circulated in the Times in August 1914. (See Appendix Article A) The page marks the end of the Battle of the Frontiers, on August 25 1914. In a series of conflicts taking place on eastern fronts, the Battle of Mons is the first time the British Expeditionary Force (BEF) and the British II Corps engage with the German army. The troops must retreat on August 24 because of an exposed eastern flank and because they become sufficiently outnumbered by more than double the number of German soldiers. If a reader glances at the layout of these articles 
reporting on this event, immediately the eye concentrates on the headlines. Presented all together, the headlines read: 'Namur Lost', 'German Success in Belgium', 'British Force Fighting Well', and 'Enemy's Heavy Losses' next to 'British Army's Stern Fight', 'Official Report' and so on. These headlines seem contradictory-they present multiple perspectives on the same event. A reader would be forced to ask the question: how can the British army be fighting well if it lost a major city?

The bold headlines tell us that these opposing ideas-that good fighting can accompany a major loss — can in fact both be true. Furthermore, the 'British Army's Stern Fight' is qualified by the following leader: 'Official Report'. Undoubtedly, a charitable reader would find it difficult to refute any information that is officially sanctioned. These appealing statements of stoicism and bravery are accompanied by the articles below which do not include specific facts, names, or figures. Instead they furnish neatly-contained tit-bits of news perforated by neat columns like this concisely-summarized point in the article on the left: 'there is as yet no explanation of its [Namur's] sudden fall'. What would the reader think could the fall have been attributed to? It could certainly have been due to the heavy casualties of the allied troops (British soldiers losses totaled 7800 by the end of these battles, the French losses are no less than staggering) or of the failure of a military plan (the French forces retreated east of Mons, therefore forcing the British to withdraw), though none of these explanations are given here.

Another possible explanation for the discrepancies outlined above may be found in the next day's edition of the Times. (See Appendix Article B) From the very beginning of the First World War, reports of 'German Barbarism'-here, again substantiated by the headline, 'Official Reports'-were widespread. These 'fearful and atrocious crimes committed willfully and deliberately by the invading hosts against helpless non-combatants, old men, women, and children' were presented as if they were evident facts have never been independently verified. It appears these accusations were designed to provide counter evidence to the image of a weak and defeated British army corps. The myth of this barbarism-which went so far as to claim that German troops mutilated children-has been well documented, but has never quite been disavowed.

In these articles on page six of the Times, soldiers do not have names, nor do any of the correspondents doing the reporting, yet a rhetoric that uses possessive pronouns is predominant. For example, the middle article from the first page displayed earlier contains the following sentence: 'Fighting has gone on more or less continuously, but the enemy has not effectively harassed our operations'. This example shows that the distinction between the self (the British) and other (the Germans) is literally marked: any underlying attitudes toward 'the enemy' surface as soon as the possessive pronoun is used. In a more subtle way, the verb choice, 'harassed', sets the tone for what action to expect from 'the enemy' and what response can be anticipated from the British military: the Germans are a persistent or relentless nuisance that are ineffective against the sober and controlled executions by the commanders of the Army Corps. The rhetorical moves I have discussed above, which occur ubiquitously throughout the newspaper, work to situate the reader in the position of an unnamed man for which the battle is being fought. In this case, the unnamed man is a British civilian, allied with the French, in the brave fight against the uncivilized and savage 
Huns. After reading a popular newspaper, it is not difficult to surmise how the notion of the Great War for Civilization becomes a common idiom.

In these articles, the actual numbers of troops are not reported, keeping the magnitude of the battle which led to 'The Fall of Namur' non-specific, and impossible to visualize, even though war correspondents themselves had vivid experiences of the battlefield such as the one described by Philip Gibbs in 1923:

We saw the whole organisation of that great machine of slaughter (...) the effect of such a vision, year in, year out, can hardly be calculated in psychological effect unless a man has a mind like a sieve and a soul like a sink.

(Gibbs, 1923, p. 253)

In other words, horrific accounts of the war written by newspaper journalists circulated, just not in newspapers. Why not report this point of view? What prevents such a vision from being reported or described in detail? My reading of these articles suggests that the layout, content, and discursive style of a mainstream newspaper like the Times treated the war, and its actors, as abstracted forces-valiant and powerful not vulnerable and powerless. Thus, the code of objectivity disallows impressionistic descriptions making impossible the sort of vision of the war given by Gibbs. Instead, the notion of objectivity reinforces an ideology of documentation and 'true' reporting.

Another conclusion can be drawn from my reading of the above articles. The relationship between national identity, national interest, and the ideology of objectivity as expressed in the popular press is naturalised because it is narrated to its public in that way: 'Our operations' are led by the 'British Army's Stern Fight' so that 'Casualties are not Heavy' even though the city of Namur was 'Lost'. And readers know this narrative is true because these 'facts' are gathered from an 'Official Report'. 'Our' operations are described in more detail in the body of the articles, but before a British civilian decides to read on, the headline, 'Casualties Not Heavy' relieves him of any distress. 'Casualties Not Heavy'; how does the reader know this caption only applies to the British forces? Indeed, this headline does not even end up applying to the allied forces in general (the French lost an estimated 27,000 in the battle at Mons) and it becomes certain that this caption does not describe German losses because we learn that 'The enemy suffered very heavily'. This caption, 'Casualties Not Heavy' can only exist where there is an implicit assumption that the public digesting this information identifies with the force that is 'fighting well', that is protecting the nation's interests, which, the public learns, turns out to be the fight against barbarism. Furthermore, this caption can only perform this function when there is an a priori assumption of objectivity - in other words, when the public believe that what it is reading is true and actually occurring in the world.

The discussion above demonstrates that mainstream newspapers such as the Times transmit a particular ideological position in identifiable ways. One could argue that the newspaper's reporting goals were identical with an imperial government's domestic and international agendas. Thus, the organisation of information in a newspaper can be understood as a formal strategy that is purposefully deployed to satisfy a uniform set of interests. I would suggest that such a deterministic view is severely limited. Instead, I contend that the indexical relation of the newspaper to the 
historical world is integral to the function of form and style of text. That is, the form (broadsheet, for instance) and style of newspaper reporting (e.g., the consistent use of possessive pronouns) is a complex mediated process-not a staged or static result: these textual outcomes are not necessarily over-determined by historical processes. However, the style of presentation is not insulated from the larger structural mode of production which sets the parameters for development either. In short, the mode of reporting in the popular press of this period, i.e., the 'New Journalism' model, is not only a result of industry growth but it is also an outcome of contestation in the wider social world.

It may seem that the historical weight of a Victorian style of reporting impacted the Times in ways that the new modes of production could not resolve alone. The social attitudes of the age mattered in the heightened popularity of one publication over another. It could be argued that despite the industrialisation of all the presses in general, the out-dated style, format, and vernacular of the Times explain the decline in sales prior to 1908. Indeed, this is often cited as the primary reason the Times was struggling financially in the early twentieth century. In contrast, I have argued that the mode of production of the press-its increase in technological dependence and adoption of a specialised division of labour-has a more direct role in its new popularity because styles follow from the processes of production. That is, changing old language structures only become effective and popular when they meet the economic and social conditions that pre-exist them. Therefore, adopting the 'New Journalistic' conventions became strategically successful in a highly-technologised industry.

But why did the mainstream press accept the authority from and responsibility to the public and choose to inform it the way it did? What compelled the industry to position itself along liberal democratic lines instead of say, right-wing or left-radical lines? I examined above in a couple of newspaper articles that the relationship between national identity, national interest, and the ideology of objectivity as expressed by the popular press is naturalised. Because a national newspaper adopts a specific combination of formal conventions, does it follow that the newspaper is therefore taking part in circulating a capitalist imperialist-centered discourse- that is, a discourse ideologically motivated to benefit a political system that seeks to exploit native and colonial labour and the raw materials and resources of foreign lands?

The professionalisation of journalism in the market-driven Edwardian period economy was paradoxical. As a result of standardisation and its exclusive access to the battlefield, the profession of journalism gains national recognition and acquires 'official' status. This unique role may allow the journalist to influence the greater public opinion on world affairs. On the other hand, this new status induces the journalist to subscribe to the ideology of free enterprise. Indeed, the professionalisation of newspapermen empowers them to reinforce a production of meaning, one predicated on a representational 'objective' discourse and supposition of 'official' truth. However, this epistemological authority is only made possible by the structures dependent upon capitalist enterprise. It is for this reason that the discourse of a mainstream national newspaper inevitably participates in the imperialist project, which must justify fighting in the Great War. 


\section{References}

Anderson, B. (1983) Imagined Communities: Reflections on the Origins and Spread of Nationalism. London: Verso.

Collini, S. (1991) Public Moralists: Political Thought and Intellectual Life in Britain, 1850-1930. Oxford: Clarendon Press.

Elliott, P. (1978) Professional Ideology and Organisational Change: The Journalist since 1800. In: Boyce, G., Curran, J. and Wingate, P., eds. Newspaper History: From the Seventeenth Century to the Present Day. London: Sage Publications, 1978, pp 172-191.

Feltes, N. N. (1986) Modes of Production of Victorian Novels. Chicago: University of Chicago Press.

Gibbs, P. (1923) Adventures in Journalism. London: Heinemann.

Hall, S. (1978) Newspapers, Parties and Classes. In Curran, J., ed. The British Press: A Manifesto. London: Macmillan, 1978, pp 30-52.

Hampton, M. (2001) Understanding Media: Theories of the Press in Britain, 18501914. Media, Culture and Society, 23(2): 213-231.

Hampton, M. (2004) Visions of the Press in Britain, 1850-1950. Urbana: University of Illinois Press.

Hobsbawm, E. (1989) The Age of Empire, 1874-1914. New York: Pantheon, Random House.

Hobsbawm, E. (1990) Nations and Nationalism since 1780: Programme, Myth, Reality. Cambridge: Cambridge University Press.

Jameson, F. (1981) The Political Unconscious: Narrative as a Socially Symbolic Act. Ithaca: Cornell University Press.

Lee, A. (1978) The Structure, Ownership and Control of the Press, 1855-1914. In: Boyce, G., Curran, J. and Wingate, P., eds. Newspaper History: From the Seventeenth Century to the Present Day. London: Sage Publications, 1978, pp 117-129.

Mandel, E. (1978) Late Capitalism. London: Verso.

Smith, A. (1978) The Long Road to Objectivity and Back Again: The Kinds of Truth We Get in Journalism. In: Boyce, G., Curran. J. and Wingate, P., eds. Newspaper History: From the Seventeenth Century to the Present Day. London: Sage Publications, 1978, pp 153-189.

Startt, J.D. (1988) Good Journalism in the Era of the New Journalism: The British Press, 1902-1914. In Wiener, J.H., ed. Papers for the Millions: The New Journalism in Britain, 1850s to 1914. London: Greenwood Press, 1988, pp 275-297. 
The Ideology of Objectivity: Constructs of Language in the Popular Press of Early TwentiethCentury Britain

Tagg, J. (1988) The Burden of Representation: Essays on Photographies and Histories. Minneapolis: University of Minnesota Press.

Times. London. 1914.

Wayne, M. (2003) Marxism and Media Studies: Key Concepts and Contemporary Trends. London: Pluto. 


\section{Appendix}

Article A:

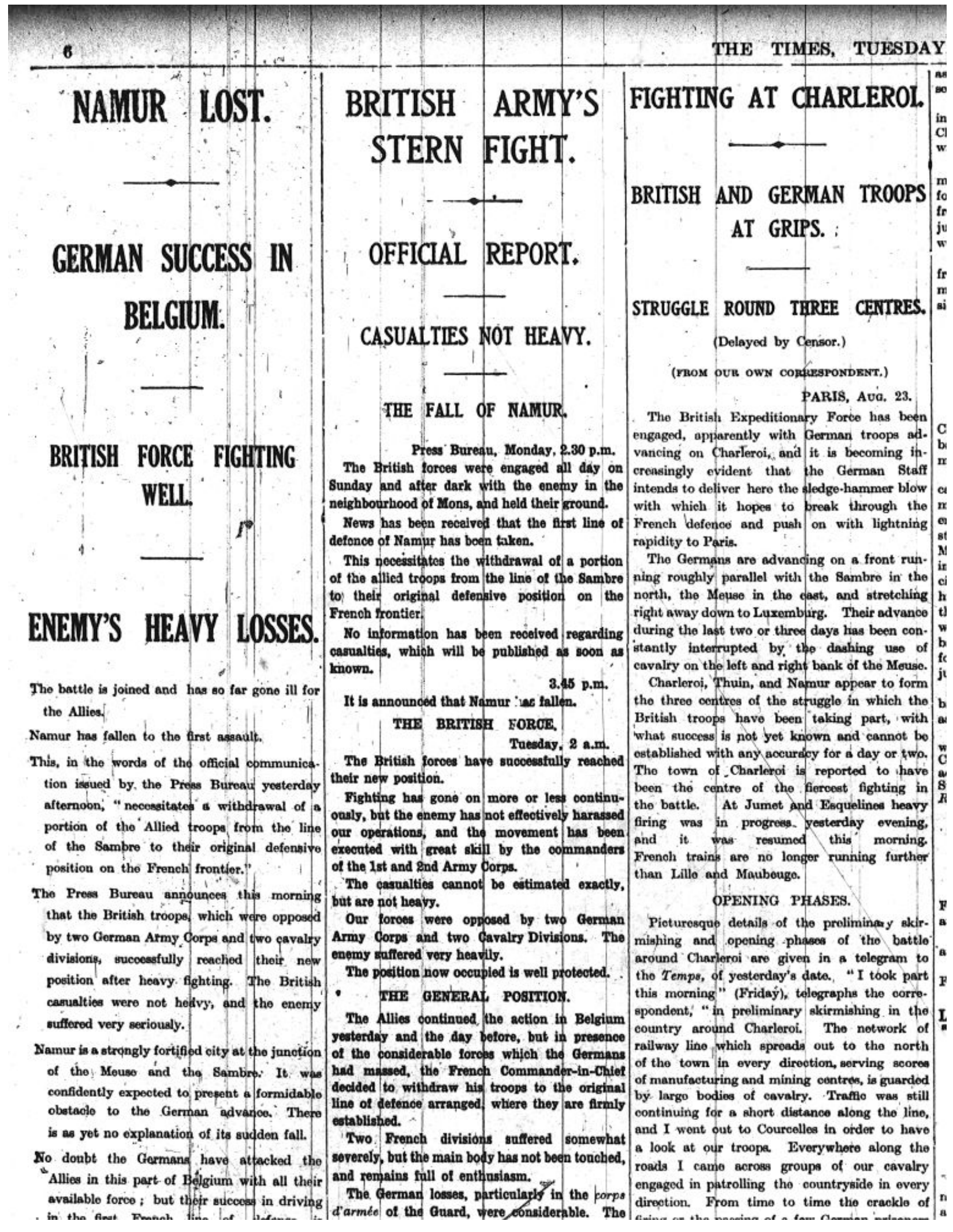


Article B:

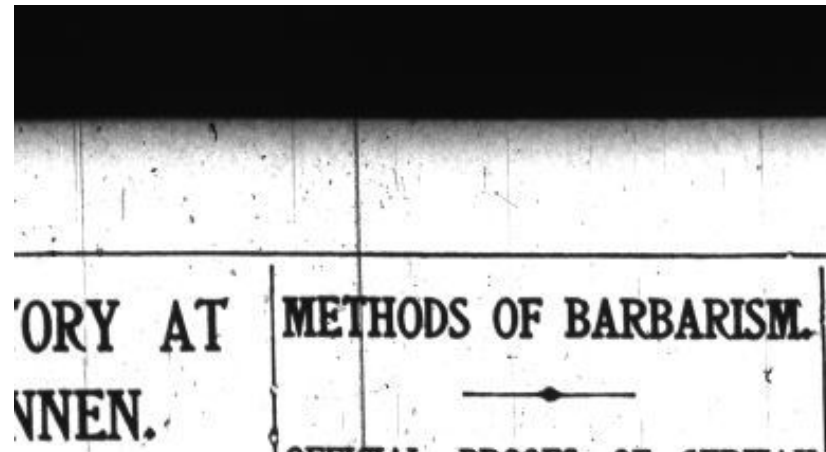

OFFICTAL PROOFS OF GERMAN OUTRAGES.

IST GERMAN

IS.

\section{LENCED BY LRY. \\ LE CHARGE.}

CORRERTONDENT)

ERBSBURG, Ava. 25.

ding the Ruexian force nen has received the ion. The Germans thers numbers and position. n. of the "best man

I her best. Although st. of cencualties is yet loseses during the recent russis are known to in the beat known familie ig the gallant cevalr Katkofts, a Bobrikoff, odsky, and among the Jartiman, a Tornau, and Duke Dmitri Pavlovitch Oleg Constantinovitch, ne Guards, rode in the will for ever be a glory the Russian Army.

ed officens' now being Guards Hospital, where I by the Empreas Mario ses, is the Vice-Governor d a line regiment as a , ranks, and received the

after having been shot de to the r noar of the had his wound drensed, on, Then he received a $\mathrm{m}$, but asked his brother d remained in the rankos d his shoulder. The liat $t$ be almokt continued

- voner mistons

of the German troops will deter the atrocities, as pouched for by the Committee of

Chief Justio Van Isoghem, Judge Nys, Pro fessors Cottier, Wodon. \&c.

INSTANCES AND PARTICULARS.

The following instances and particulara have witnesess :-

\section{THE TMMES, WEDNESDAY, AUGUST}

mandant Georges Cilmon, of the - pth Infantry of the Line, now lying in bospital at Antwarp:-

"I was told to cover the retreat of our troope in front of Aersehot. During the vetion fought there on Wednesday, Angust 19, between 6 and 8 o'clock in the morning. suddenly I saw on the high road, between the Górman and Behgian forces, which were fighting at close range, a group of four women, with babies in their arms, and two littlo girls elinging to their skirta. Our men stopped firing till the women got through our lines, but the German machine-guns went on firing all the time, and one of the women was wounded in the arm. These women could not have got through the neighbouring German lines and been on the high road unles with the consent of the enemy.

"All the ovidence and circumstances seem to point to the fact that thoee women had been deliberately pushed forwand by the Germana to set as a shield for their advanee guand, and in the hope that the Belgians would dease firing fo fear of killing the women and children."

This statement was made and duly certified in the Antwerp hospital on August 22 by Commandant Gilmon in the preeence of the Chevalier Ernst N. Bunswyck, Chief secretary to the Belgian Minister of Justice, and M. de Cartier de Marahienno, Belgian Minister to China

In publishing the above statements the only comment the Proes : Burean can offer is that these strocities appear to be committed in villages and throughout the countryside with villages and throughout the countryside with the deliberate intention of terrorizing the people, and so making it unnecenary to leave troops of communication. In large plaoes like Brues, where the diplomatio representatives of neutral Powers are eyo-witnesses, thero appear to have been no excesses.

\section{THE GOEBEN CHASE.} Belgian Government from protesting before the civilized world against the fearful and atrocious erimes committed wilfully and deliberately by the invading hosts against helpless non-oopbatants, old men, women, and childron. Long is the list of outrages committed by the German troops and appalling the details of Inquiry recently formed by the Belgian Minister of Justice and presided over by him. This commityeo comprises the highest judicial and university suthorities of Belgium, such as been esfablished by caroful investigations based in each caee on the evidence of reliable oyeGerman cavalry oocupying the village of other wide. British oruiser came in here to coal

“ WELL DONE, GLOUCESTER."

(TROM OUB STECLL CORRESPONDENT.) MalTA, Ava. 14.

In her- pursuit of the Breslau and the Goeben the littlo British cruimer Gloucester indulged in some long-range shots at 11,000 yards at the Breslan, and apparently put the German cruiser's after-gun out of nction. This was when she - was chasing the two shipe among the Ionian Islands, kooping watch on them after they had run from Messina. The Gloucester narrowly escaped destruction trom a toreben, which A her the a her coanort. The Broblu alo noexly hit the guns. One projectile fell just short, and the Wher wide.

When the Britinh oruiser came in hero to coal

\section{ZEPPELIN} ANT

\section{SEVERAL PE}

\section{HOSPITAL PAR}

(From our Spec

At 1 o'olock this $x$ by heavy explosions city, eaused by a : having excaped the eireled round, droppi King's Palace, the Bo the Hoepital of St. I where the various One house in the $R$ entisely demolished. lous escape, being firemen three hours I Unfortunately five neveral injured, incluc bomb which burst Chevaux.

This mothod of non-oombetanta has dignation among the seen a piece of one o is over 3 in. thick, an enormous size.

(Coryriant Teleara)

At fint it was repol been fired on and br six miles from Antwr capturod. This rep firmed, and apparent It is believed that t railway station was visit.

One bomb, accordi destroyed part of the but luckily no one was flying the flag of $t$ A miesage from Company states that and the Princes Loo places where the

\section{GERMANS}

THE RETREAT 
